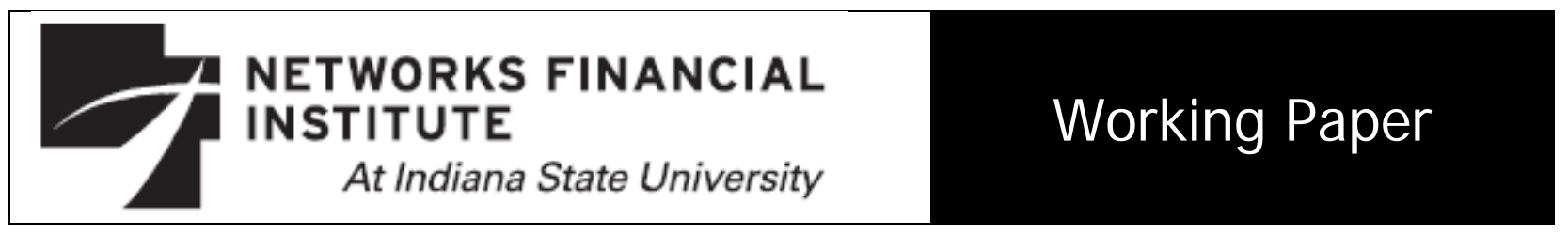

2009-WP-04

May 2009

\title{
Performance of Debt Free Firms
}

Tarek Zaher

Abstract: This paper compares the performance of portfolios of debt free firms to comparable portfolios of leveraged firms. The results of the study indicate that investments in portfolios of debt free firms tend to generate higher returns than investments in their peer portfolios of leveraged firms over long and short periods. The results have clear implications for investment decisions and investment performance. Investors tend to reward firms that resist the urge to borrow heavily and operate with debt free balance sheets and penalize firms that have high levels of debt. Moreover, during market downturns, debt free firms will not have the additional burden of debt and may be able to recover much faster than companies that carry a debt load over a long period of time, and therefore would outperform leveraged firms. This latter assertion may be retested after the latest international financial crises come to an end.

About the Author: Tarek Zaher is a Professor of Finance, Indiana State University College of Business. Dr. Zaher completed his Ph.D. at the University of Texas at Dallas. He has taught at Indiana State University since 1990 and previously taught at the University of Texas at Arlington. Dr. Zaher has held professional jobs with and provided consulting services to a number of companies in the United States and abroad. Dr. Zaher also has offered seminars in investment and international finance at institutions around the world and has published in numerous scholarly journals. Dr. Zaher's primary research is in financial markets and institutions and investment, with a special interest in emerging markets including the Middle Eastern and North African (MENA) markets.

Keywords: Equity firms, capital structure, debt free firms, debt and stocks.

The views expressed are those of the individual author and do not necessarily reflect official positions of Networks Financial Institute. Please address questions regarding content to Tarek Zaher at tzaher@isugw.indstate.edu. Any errors or omissions are the responsibility of the author.

NFI working papers and other publications are available on NFI's website (www. networksfinancialinstitute.org). Click "Research" and then "Publications/Papers." 


\section{Performance of Debt Free Firms}

\section{Tarek Zaher}

\section{Introduction}

Many investors believe that the earnings of a company drive the returns to shareholders in the form of rising stock prices. For these investors, the profit and loss statement, which reports a company's earnings, receives most of the attention. Other investors believe that the balance sheet is an important tool in assessing the financial health and the risk inherent in a company. One of the key items on the balance sheet is the level of debt. Companies with no debt are usually hailed by investors for displaying a conservative financial approach. The absence of debt means that the company is able to grow, if in fact it does, without incurring debt, and this, in turn, suggests a business that generates lots of surplus cash. It also provides the company with financial flexibility to take on debt to fund expansion, make an acquisition, or if conditions sour, to borrow some money until business improves. While this shows the strength of a debt free company, debt in and of itself is not necessarily a bad thing. Debt is a cheap source of funding for most companies. In addition, the interest cost paid by a leveraged firm is tax deductible and therefore reduce the firm's tax liability, adding to the appeal of debt funding. However, debt can grow to levels where its fixed interest and principal commitments stifle the company's ability to operate freely and effectively. This can lead to default on interest payments, and may lead to financial distress or to firm bankruptcy.

High debt levels may also limit the ability to pay dividends as surplus cash may be needed to service debt. However, high levels of debt are only a problem if they cannot be financed. While the heavy use of debt has over time hammered many large firms in the U.S.A. and other countries, it is not clear whether investors reward companies that resist the urge to borrow and operate with a debt free balance sheet.

In this study, I examine whether firms that shun debt are rewarded. In particular, I compare the performance of portfolios of debt free firms to comparable portfolios of leveraged firms. The results of this study indicate that investments in portfolios of debt free firms tend to generate higher returns than investments in their leveraged peers. These results imply that investors tend to reward firms that resist the urge to borrow heavily and operate with a debt free balance sheet, and they tend to penalize firms that have high levels of debt. 
The remainder of the paper is organized as follows: Section 2 summarizes the previous literature. In Section 3, I describe the data and the methodology applied to my study. The empirical results are presented in Section 4 and section 5 presents the summary and conclusions.

\section{Literature Review}

The impact of capital structure on the value of the firm has been a puzzling issue in corporate finance since the capital structure "irrelevance" proposition introduced by Miller-Modigliani (1958, MM hereafter). Many research studies have been conducted on theories of capital structure, determinants of capital structure and on the existence of an optimal capital structure. The tax-based theories introduced first by MM emphasize the role of tax advantage of debt financing and argue that the value of the firm will increase with more leverage. Proponents of agency theory argue that firm leverage is positively associated with firm value (Harris and Raviv 1990, Stulz 1990, probability of default (Harris and Raviv 1990), liquidation value (Williamson 1988) and free cash flow (Jensen 1986 and Stulz 1990). Proponents of the information and signaling hypothesis propose two streams of arguments. The first argument emphasizes the role of debt in conveying inside information to the market (Ross 1977). The second argument introduced by Myers and Majluf (1984) highlights the role of leverage in alleviating the problem of suboptimal managerial behavior.

The capital structure literature, on the other hand, has indicated that limited work has been undertaken in examining leverage as an independent variable or a risk factor in explaining stock returns due to the overwhelming influence of $\mathrm{MM}$, whch argues that the value of a firm is determined by the rate of return on assets and not by the mix of securities it issues. The implication of MM propositions on equity returns is that returns should increase with leverage. However, the empirical evidence on the relationship between financial leverage and stock returns is contradictory and mixed.

Some studies suggest that there is a positive relationship between leverage and stock returns. Hamada (1972) tests the relationship between a firm's leverage and its common stock's systematic risk over a cross section of firms. He adjusts the observed rate of return of a stock to what it would have been over the same time period had the firm no debt and preferred stock in its capital structure. He concludes that firms which have debt have higher returns. Bhandari (1988) 
also provides evidence that common stock returns increase with leverage. He uses the FamaMacbeth methodology to estimate beta, and the book value of debt to market value as a measure of leverage; he conducts his tests in the cross section of all firms without assuming different risk classes.

Other studies provide evidence that there is a negative relationship between leverage and stock returns. Dimitrov and Jain (2005) measure the effect of changes in leverage on stock returns as well as earnings based measures of performance. Their results revealed negative correlation between leverage ratio and risk adjusted stock returns. Fama \& French (1992) found that leverage based on book values is associated with lower average returns, whereas leverage based on market is associated with higher returns. They concluded that this variation in their findings is explained and absorbed by the book-to-market effect. Korteweg (2004) also reports a negative relation between stock returns and leverage. Penman et al (2007) examined the bookto-price effect in stock returns by accounting for leverage. They break down the book-to-price component into enterprise book-to-price which reflects the operating risk and a leverage component that reflects financing risk. They find that leverage is negatively related to returns and found this evident in firms with both high and low book-to-price companies.

\section{Data and Methodology}

\section{A. Data and samples selection}

My data set begins with all publicly traded U.S. Corporations that are available on the Center for Research in Security Prices (CRSP) and Compustat database from the period January 1997June 2007. Two samples of firms are extracted from the databases, a debt free firm sample and a leveraged firm sample. Debt free firms are firms with a zero debt to total asset ratio, and leveraged firm are firms with a debt ratio that is equal or greater than $30 \%$. I first selected the firms that will enter the debt free sample. The requirement for each firm to enter the sample is to have a zero debt to total asset ratio and have stock returns series available for the period of the study. The firms in the debt- free sample firms were sorted by sector and size (measured by total assets). The leveraged firm sample was then constructed by matching the debt free firms with leveraged firms from the same sector and with similar size. Only eight sectors contained debt free firms for the period of study. These are energy, basic materials, industrials, consumer discretionary, consumer's staples, healthcare, financials and technology. 
Descriptive statistics (monthly mean return, average standard deviation, and average coefficient of variation) and two performance measures, Jensen's alpha and the annualized information ratio are then computed for the portfolios of debt free firms and leveraged firms in each of sectors and the combined portfolios of all sectors for each group. The analysis is performed over the whole period of study (1998-2007) and was repeated for a shorter period, June 2002-June 2007.

The book value of debt and total assets from the Compustat database are used to compute the debt ratio. The monthly return data for individual firms and market indexes are extracted from the CRSP database. The return on the three month Treasury bill is obtained from online Federal Reserve data.

\section{B. Research Method}

In this research I use two alternative measures of performance to compare the performance of debt free firms and leveraged firms, the Jensen's alpha $\alpha_{p}$; and the Sharp information ratio, $S_{p}$. Jensen's alpha depends on beta as a measure of the risk of the portfolio. I estimate the Jensen's alpha $\alpha_{p}$ as:

$$
r_{p t}=\alpha_{p}+\beta_{p} r_{m t}+\varepsilon_{p}
$$

Where $r_{p t}$, is the excess return (i.e., the observed return minus the risk free rate) on the portfolio $p$ in month $t, r_{m t}$ is the excess return on the benchmark or market portfolio in month $t, \beta_{p}$ is portfolio $p$ 's beta, and $\varepsilon_{p t}$ is the residual term during period $t$.

The second measure of investment performance is the Sharp information ratio. This statistic measures the portfolio's average return in excess of a benchmark portfolio divided by the standard deviation of this excess return. The information ratio is calculated as

$$
I R_{j}=\left(R_{j}-R_{b}\right) / \sigma_{E R}
$$

Where:

$I R_{j}=$ the information ratio for portfolio $j$

$R_{j}=$ the average return for portfolio $j$ during the specified time period

$R_{b}=$ the average return on the benchmark or market portfolio during the period 
$\sigma_{E R}=$ the standard deviation of the excess return during the period

Goodwin (1998) showed that if excess portfolio returns are estimated with historical data using the same single factor model used to estimate Jensen's alpha, the IR simplifies to

$$
I R_{j}=\alpha_{j} / \sigma_{e}
$$

Where $\sigma_{e}$ is the standard error from the regression in equation 1.

To convert the information ratio that is based on a periodic returns measured $T$ times per year to an annualized information ratio, the following formula is used:

$$
\text { Annualized IR }=(T) \alpha_{j} /\left(T^{\wedge} 0.5\right) \sigma_{e}=\left(T^{\wedge} 0.5\right) I R
$$

Grinold and Khan (2000) suggest that a reasonable information ratio should fall between 0.5 and 1.0. Annualized Information ratio of 0.5 indicates good performance and an IR of 1.0 indicates exceptional performance.

\section{Results}

The characteristics of the portfolio of debt free firms are compared with the matching leveraged portfolio using a Wilcoxon two-sample rank sum test. Table 1 provides the descriptive statistics (monthly mean return, average standard deviation and average coefficient of variation) of the portfolios of leveraged firms and debt free firms and the Z-scores from the Wilcoxon test for the period January1998-June 2007. The Z-scores indicate that the mean monthly return of debt free firms is significantly different from that of the leveraged firms. The Z-score is 1.68 and is significant at the 10 percent level. However the standard deviation of monthly return is not significant as indicated by a $1.19 \mathrm{Z}$-score from the Wilcoxon test. The average coefficient of variation for the two groups is also not significant (Z-score is 0.70 ), indicating that in terms of total variability of monthly return, rather than market-related variability, debt free firms and leveraged firms have comparable volatility.

The Z-scores for the short period 2002-2007 shown in table 2 indicate that there is no significant difference in the descriptive statistics (mean return, average standard deviation and average coefficient of variation) between the leveraged portfolios and debt free portfolios. The 
estimated Z-scores are $0.140,0.001$, and 0.420 . The Z-scores indicate that, over the short period of the study, the debt free portfolios and leveraged portfolios have comparable mean monthly and total variability.

Table 3 reports the estimated beta from the regressions, the performance measures (Jensen's alpha and Sharp IR) and the Z-scores for difference in means over the (January 1998-June 2007). The Jensen's alpha was computed from equation (1) using NASDAQ equally weighted index from the CRSP as a benchmark. Sharp IR is calculated by dividing the estimated alpha from the regression in equation (1) by the regression standard error. This statistics is then annualized by multiplying the monthly IR by the square root of 12 .

The alpha estimates in table 3 are positive and statistically significant for the debt free portfolios of all individual sectors except the portfolio from the consumer staples sector. The alpha is also positive and significant for all sectors debt free portfolio.

The alpha estimates for the leveraged portfolios are positive and statistically significant for only four of the eight portfolios, industrials, consumer staples, health care and financials, but it is significant for the all sectors portfolio and the remaining four sectors. The size of alpha is larger for the debt free for all portfolios with the exception of the consumer staples portfolio. The results suggest that debt free portfolios outperform their leveraged peers.

The above conclusion is also supported by the results from the estimated annualized Sharp information ratio. The annualized IR for the combined debt free portfolio is 1.278 and ranges between 0.54 and 0.97 for all the individual sector portfolios. The only exception is the consumer staples portfolio. These estimated annualized IR suggest very good to exceptional performance for the debt free group of portfolios. The estimated annualized IR for the leveraged firms portfolios are mostly below 0.5 for five of the eight sectors and for the combined portfolio. These results suggest that the leveraged firms' portfolios underperform the matching debt free portfolios. The results of the Wilcoxon two-sample test also confirm these findings. The Z-score for the Jensen's alpha is 1.836 and the Z-score for the annualized Sharp IR is 1.63. Both Zscores are significant at the $10 \%$ level. However, the Z-score for the difference in beta means is not statistically significant, indicating that there is no difference in systematic risk between the debt free and leveraged portfolios. The later finding indicate that a portfolio of debt free securities constructed from the eight sectors examined in this study will outperform a comparable portfolio of leveraged firms. 
The results of performance measures' analysis over the shorter period 2002-2007 are summarized in table 4 . The results also support, but to a lesser extent, the findings over the long period. The alpha estimates are positive and statistically significant for the debt free portfolios in the energy, materials, industrials, consumer discretionary and financials. It is also positive and significant for the debt free portfolio that contains firms from all sectors. However, the alpha is not significant for the portfolios in the consumer staples, health care and information technology (IT) sectors.

The alpha estimates for the leveraged portfolios are positive and statistically significant for the portfolio from the energy sector and the consumer staples sector, and it is not significant for the portfolios from the remaining sectors. In general the size of alpha is larger for the debt free portfolios than the leveraged portfolios. These results indicate again that portfolios of debt free firms outperformed their leveraged portfolios peers. The annualized Sharp information ratio estimates in table 4 also provides support to the findings from the alpha measure analysis. The annualized IR is larger for portfolios of the debt free firms than the comparable portfolios of leveraged firms for six out of the eight sectors. It is also larger for the combined debt free portfolio. The estimated annualized IR suggests very good to exceptional performance for the debt free group of portfolios. However the results of the Wilcoxon two-sample test indicate that there is no significant difference in the beta, alpha or the annualized IR as indicated by the Zscores of $0.280,1.2820$, and 1.1700 respectively. The results from the short period support the findings over the longer period (1998-2007) that the debt free firms outperform their peers of leveraged firms.

The findings here support those of Dimitrov and Jain (2005), Korteweg (2004), and Penman et al (2007), all of whom provide evidence that that there is a negative relationship between leverage and stock returns, and contradicts the studies by Bhandari (1988), Hamada (1972), who argue that stock returns increase with leverage.

\section{Conclusion}

This study aims to find out whether investors reward firms that shun debt. It compares the performance of portfolios of debt free firms to comparable portfolios of leveraged firms. Debt free firms are matched with conventional firms of the same size from the same sector. Tests of differences in the performance are conducted for a long period and for a short period. The 
results of this study indicate that investments in portfolios of debt free firms tend to generate higher returns than investments in their peers of portfolios of leveraged firms over long and short periods. The evidence presented here has clear implications for investment performance.

Investors tend to reward firms that resist the urge to borrow and operate with debt free balance sheets and penalize firms that have high levels of debt.

During market downturns, debt free firms will not have the additional burden of debt, and may be able to recover much quicker than companies having to deal with slowing and declining sales growth as well as carrying a debt load over a long period of time, and therefore would outperform their peers of leveraged firms. This later assertion may be retested after the late international financial crises come to an end. 


\section{References}

Bhandarim, L. C. (1988). Debt/Equity Ratio and Expected Common Stock Returns: Empirical Evidence. Journal of Finance XLIII: 507-528.

Bradley M., Jarrell G.A. and Kim H. E. (1984). On the Existence of an Optimal Capital Structure: Theory and Evidence. Journal of Finance Vol XXXIX (3): 857-878.

Dimitrov, V. and Jain P. C. (2005). The Value Relevance of Changes in Financial Leverage http://ssrn.com/abstract $=708281$.

Fama, E. F. and French, K. (1992). The cross-section in expected stock returns. Journal of Finance 47 427-466.

Fama, E. F. and MacBeth, J. D. (1981). Risk, Return and Equilibrium: Empirical Tests. Journal of Political Economy 73: 607-636.

Goodwin, T. H. (1998). The Information Ratio. Financial Analysts Journal 54, no 4 (JulyAugust): $34-43$.

Grinold, R. C. and Ronald N. Khan. (1994). Active Portfolio Management, $2^{\text {nd }}$ ed. New York: McGraw Hill.

Harris, M. and Raviv, A. (1990a). Capital Structure and the Informational Role of Debt. Journal of Finance 45: 321-349.

Harris, M. and Raviv, A. (1991). The Theory of Capital Structure. Journal of Finance XLVI (1): 297-355.

Jensen, M. C. (1986). Agency Costs of Free Cash Flow, Corporate Finance and Takeovers. American Economic Review 76(2): 305-360.

Korteweg, A. (2004). Financial Leverage and Expected Stock Returns: Evidence from Pure Exchange Offers. http://ssrn.com/abstract $=597922$

Modigliani, F. and Miller, M. H. (1958). The cost of capital, corporation finance and the theory of investment. American Economic Review 48(3): 261- 297.

Muradoglu, G. and Whittington, M. (2001). Predictability of UK stock returns by using debt ratios. CUBSFinance Working Paper No 05. http://ssrn.com/abstract=287653.

Myers, S. C., and Majluf, N. S. (1984). Corporate Financing and Investment Decisions When Firms Have Information That Investors Do Not Have. Journal of Financial Economics 13 (June): $187-221$. 
Penman, S. H., Richardson, S. A. and Tuna, I. (2007). The Book-to-Price Effect in Stock Returns: Accounting for Leverage. Journal of Accounting Research 45(2): 427-467.

Ross, S. A. (1977). The Determination of Financial Structure: The Incentive-Signaling Approach. Bell Journal of Economics 8(1): 23-34.

Stulz, R.M. (1990). Managerial Discretion and Optimal Financing Policies. Journal of Financial Economics 26 (1): 3-28.

Williamson, O.E. (1988). Corporate Finance and Corporate Governance. Journal of Finance 43 (3): 567591. 
Table 1: Descriptive Statistics of Debt Free Portfolios and Leveraged Portfolios, 1998 - 2007

Debt free firms $\quad$ Leveraged firms

Panel A: Energy Sector

\begin{tabular}{lll}
\hline Mean Monthly Return \% & 0.0181 & -0.073 \\
Average Standard Deviation & 0.0635 & 0.2701 \\
Average Coefficient of Variation & 3.5054 & -36.817 \\
Average Debt Ratio & 0 & 0.3906 \\
Sample Size & 13 & 37
\end{tabular}

Panel B: Materials Sector

Mean Monthly Return \%
Average Standard Deviation

$0.0190 \quad 0.0102$

$0.0753 \quad 0.0533$

Average Coefficient of Variation

3.9545

5.2159

Average Debt Ratio

0

Sample Size

6

0.4038

18

Panel C: Industrial Sector

\begin{tabular}{lll}
\hline Mean Monthly Return \% & 0.0169 & 0.0159 \\
Average Standard Deviation & 0.0627 & 0.0623 \\
Average Coefficient of Variation & 3.7180 & 3.9177 \\
Average Debt Ratio & 0 & 0.4051 \\
Sample Size & 12 & 41
\end{tabular}

Panel D: Consumer Discretionary Sector

\begin{tabular}{lll}
\hline Mean Monthly Return \% & 0.0174 & 0.0140 \\
Average Standard Deviation & 0.0570 & 0.0574 \\
Average Coefficient of Variation & 3.2826 & 4.0983 \\
Average Debt Ratio & 0 & 0.4689 \\
Sample Size & 27 & 58
\end{tabular}

Table 1 provides the descriptive statistics (mean monthly return, average standard deviation, average coefficient of variation, average debt ratio, and sample size) of the portfolios of leveraged firms and debt free firms. The Z-scores for the difference in means of monthly return, average standard deviation and average coefficient of variation are $1.68^{* *}, 1.19$, and 0.70 respectively.

* Significant at the $5 \%$ level

** Significant at the $10 \%$ level 
Table 1: Descriptive Statistics of Debt Free Portfolios and Leveraged Portfolios, 1998 - 2007 (cont.)

Debt free firms $\quad$ Leveraged firms

Panel F: Consumer Staples Sector

\begin{tabular}{lll}
\hline Mean Monthly Return \% & 0.0077 & 0.0156 \\
Average Standard Deviation & 0.0588 & 0.0522 \\
Average Coefficient of Variation & 7.6342 & 3.3532 \\
Average Debt Ratio & 0 & 0.4399 \\
Sample Size & 5 & 15
\end{tabular}

Panel G: Health Care Sector

\begin{tabular}{lll}
\hline Mean Monthly Return \% & 0.0221 & 0.0192 \\
Average Standard Deviation & 0.1064 & 0.0642 \\
Average Coefficient of Variation & 4.8184 & 3.3520 \\
Average Debt Ratio & 0 & 0.3791 \\
Sample Size & 21 & 16
\end{tabular}

Panel H: Financial Sector

\begin{tabular}{lll}
\hline Mean Monthly Return \% & 0.0124 & 0.0116 \\
Average Standard Deviation & 0.0410 & 0.0340 \\
Average Coefficient of Variation & 3.3109 & 2.9269 \\
Average Debt Ratio & 0 & 0.5604 \\
Sample Size & 13 & 110
\end{tabular}

Panel I: IT Sector

Mean Monthly Return \% $\quad 0.0227 \quad 0.0162$

Average Standard Deviation $\quad 0.0952 \quad 0.0866$

Average Coefficient of Variation $\quad 4.1947 \quad 5.3632$

Average Debt Ratio $\quad 0 \quad 0.3869$

$\begin{array}{lll}\text { Sample Size } & 37 & 8\end{array}$

Panel J: All Sectors

\begin{tabular}{lll}
\hline Mean Monthly Return \% & 0.0188 & 0.0110 \\
Average Standard Deviation & 0.0587 & 0.0508 \\
Average Coefficient of Variation & 3.1179 & 4.6351 \\
Average Debt Ratio & 0 & 0.4219 \\
Sample Size & 134 & 452
\end{tabular}

Table 1 provides the descriptive statistics (mean, average standard deviation average coefficient of variation, average debt ratio, and sample size) of the portfolios of leveraged firms and debt free firms. The $\mathrm{Z}$-scores for the difference in means of monthly return, average standard deviation and average coefficient of variation are $1.68^{* *}, 1.19$, and 0.70 respectively.

* Significant at the $5 \%$ level

** Significant at the $10 \%$ level 
Table 2: Descriptive Statistics of Debt Free Firms \& Leveraged Firms, June 2002-June 2007

\begin{tabular}{|c|c|c|}
\hline Sector & Debt free firms & Leveraged firms \\
\hline \multicolumn{3}{|l|}{ Panel A: Energy Sector } \\
\hline $\begin{array}{l}\text { Mean Monthly Return \% } \\
\text { Average Standard Deviation } \\
\text { Average Coefficient of Variation } \\
\text { Average Debt Ratio } \\
\text { Sample Size }\end{array}$ & $\begin{array}{l}0.0228 \\
0.0540 \\
2.3643 \\
0 \\
13\end{array}$ & $\begin{array}{l}0.0247 \\
0.0537 \\
2.1722 \\
0.3906 \\
37\end{array}$ \\
\hline \multicolumn{3}{|l|}{ Panel B: Materials Sector } \\
\hline $\begin{array}{l}\text { Mean Monthly Return \% } \\
\text { Average Standard Deviation } \\
\text { Average Coefficient of Variation } \\
\text { Average Debt Ratio } \\
\text { Sample Size }\end{array}$ & $\begin{array}{l}0.0230 \\
0.0699 \\
3.0356 \\
0 \\
6\end{array}$ & $\begin{array}{l}0.0153 \\
0.0499 \\
3.2493 \\
0.4038 \\
18\end{array}$ \\
\hline \multicolumn{3}{|l|}{ Panel C: Industrial Sector } \\
\hline $\begin{array}{l}\text { Mean Monthly Return \% } \\
\text { Average Standard Deviation } \\
\text { Average Coefficient of Variation } \\
\text { Average Debt Ratio } \\
\text { Sample Size }\end{array}$ & $\begin{array}{l}0.0202 \\
0.0531 \\
2.6251 \\
0 \\
12\end{array}$ & $\begin{array}{l}0.0235 \\
0.0600 \\
2.5540 \\
0.4051 \\
41\end{array}$ \\
\hline \multicolumn{3}{|c|}{ Panel D: Consumer Discretionary Sector } \\
\hline $\begin{array}{l}\text { Mean Monthly Return \% } \\
\text { Average Standard Deviation } \\
\text { Average Coefficient of Variation } \\
\text { Average Debt Ratio } \\
\text { Sample Size }\end{array}$ & $\begin{array}{l}0.0103 \\
0.0464 \\
4.4811 \\
0 \\
27\end{array}$ & $\begin{array}{l}0.0135 \\
0.0495 \\
3.6721 \\
0.4689 \\
58\end{array}$ \\
\hline \multicolumn{3}{|l|}{ Panel E: Consumer Staples Sector } \\
\hline $\begin{array}{l}\text { Mean Monthly Return \% } \\
\text { Average Standard Deviation } \\
\text { Average Coefficient of Variation } \\
\text { Average Debt Ratio } \\
\text { Sample Size }\end{array}$ & $\begin{array}{l}0.0023 \\
0.0348 \\
14.676 \\
0 \\
5\end{array}$ & $\begin{array}{l}0.0204 \\
0.0513 \\
2.5097 \\
0.4399 \\
15\end{array}$ \\
\hline
\end{tabular}

The table provides the descriptive statistics (mean, average standard deviation, average coefficient of variation, average debt ratio, and sample size) of the portfolios of leveraged firms and debt free firms. The $\mathrm{Z}$-scores for the difference in means of monthly return, average standard deviation and average coefficient of variation are $0.140,0.001$, and 0.420 respectively.

* Significant at the $5 \%$ level

** Significant at the $10 \%$ level 
Table 2: Descriptive Statistics of Debt Free Firms \& Leveraged Firms, June 2002-June 2007 (cont.)
Debt free firms
Leveraged firms

Panel F: Health Care Sector

\begin{tabular}{lll}
\hline Mean Monthly Return \% & 0.0236 & 0.0170 \\
Average Standard Deviation & 0.0792 & 0.0570 \\
Average Coefficient of Variation & 3.3538 & 3.3470 \\
Average Debt Ratio & 0 & 0.3791 \\
Sample Size & 21 & 16
\end{tabular}

Panel G: Financial Sector

\begin{tabular}{lll}
\hline Mean Monthly Return \% & 0.0163 & 0.0137 \\
Average Standard Deviation & 0.0345 & 0.0330 \\
Average Coefficient of Variation & 3.1067 & 2.3955 \\
Average Size & 1719.79 & 3363.05 \\
Average Debt Ratio & 0 & 0.5604 \\
Sample Size & 13 & 110
\end{tabular}

Panel H: IT Sector

\begin{tabular}{lll}
\hline Mean Monthly Return \% & 0.0200 & 0.0194 \\
Average Standard Deviation & 0.0663 & 0.0732 \\
Average Coefficient of Variation & 3.3119 & 3.7600 \\
Average Size & 507.89 & 1372.07 \\
Average Debt Ratio & 0 & 0.3869 \\
Sample Size & 37 & 8
\end{tabular}

Panel I: All Sectors

Mean Monthly Return \% $\quad 0.0180 \quad 0.0171$

Average Standard Deviation $\quad 0.0452 \quad 0.0378$

Average Coefficient of Variation $\quad 2.5081 \quad 2.2090$

Average Debt Ratio $\quad 0 \quad 0.4219$

Sample Size $134 \quad 452$

The table provides the descriptive statistics (mean, average standard deviation, average coefficient of variation, average debt ratio, and sample size) of the portfolios of leveraged firms and debt free firms. The Z-scores for the difference in means of monthly return, average standard deviation and average coefficient of variation are $0.140,0.001$, and 0.420 respectively.

* Significant at the 5\% level

** Significant at the $10 \%$ level 
Table 3: Performance of Portfolios of Debt Free Firms \& Matching Portfolios of Leveraged Firms, January 1998-June 2007
Debt free firms
Leveraged firms

Panel A: Energy Sector

\begin{tabular}{lll}
\hline Beta & 0.4105 & 1.0265 \\
Jensen's $\alpha$ & $0.0135^{*}$ & -0.0143 \\
Sharp IR & 0.767 & -0.186
\end{tabular}

Panel B: Materials Sector

\begin{tabular}{lll}
\hline Beta & 0.4667 & 0.7886 \\
Jensen's $\alpha$ & $0.0142^{*}$ & 0.0041 \\
Sharp IR & 0.676 & 0.360
\end{tabular}

Panel C: Industrial Sector

\begin{tabular}{lll}
\hline Beta & 0.9501 & 0.8619 \\
Jensen's $\alpha$ & $0.0101^{*}$ & $0.0095^{*}$ \\
Sharp IR & 0767 & 0.673
\end{tabular}

Panel D: Consumer Discretionary Sector

\begin{tabular}{lll}
\hline Beta & 0.9454 & 0.8807 \\
Jensen's $\alpha$ & $0.0106^{*}$ & $0.0075^{* *}$ \\
Sharp IR & 0.977 & 0.629
\end{tabular}

Panel E: Consumer Staples Sector

\begin{tabular}{lll}
\hline Beta & 0.2624 & 0.4183 \\
Jensen's $\alpha$ & 0.0037 & $0.0109^{*}$ \\
Sharp IR & 0.221 & 0.774
\end{tabular}

The table provides a comparison of portfolio performance using the Jensen's alpha and Sharp information ratio across all the sectors. Jensen's alpha was computed from equation (1) using a NASDAQ equally weighted index from the CRSP as a benchmark. The information ratio was annualized by multiplying the monthly IR calculated from equation (3) by the square root of 12 , as shown in equation (4). The Z-scores for Estimated Beta, Jensen's alpha and the annualized Sharp information ratio are $0.140,1.836,{ }^{* *}$ and $1.63^{* *}$

* Significant at the $5 \%$ level

**Significant at the $10 \%$ level 


\title{
Table 3: Performance of Portfolios of Debt Free Firms \& Matching Portfolios of Leveraged Firms, January 1998-June 2007 (cont.)
}

\author{
Debt free firms $\quad$ Leveraged firms
}

Panel F: Health Care Sector

\begin{tabular}{lll}
\hline Beta & 1.3974 & 0.8320 \\
Jensen's $\alpha$ & $0.0136^{* *}$ & $0.0129^{*}$ \\
Sharp IR & 0.855 & 0.549
\end{tabular}

Panel G: Financial Sector

\begin{tabular}{lll}
\hline Beta & 0.4681 & 0.3516 \\
Jensen's $\alpha$ & $0.0075^{*}$ & $0.0072^{*}$ \\
Sharp IR & 0.737 & 0.7825
\end{tabular}

Panel H: IT Sector

\begin{tabular}{lll}
\hline Beta & 1.1188 & 1.1477 \\
Jensen's $\alpha$ & $0.0128^{*}$ & 0.0086 \\
Sharp IR & 0.842 & 0.431
\end{tabular}

Panel I: All Sectors

\begin{tabular}{lll}
\hline Beta & 0.6804 & 1.0910 \\
Jensen's $\alpha$ & $0.0117^{*}$ & 0.0053 \\
Sharp IR & 1.278 & 0.451
\end{tabular}

The table provides a comparison of portfolio performance using the Jensen's alpha and Sharp information ratio across all the sectors. Jensen's alpha was computed from equation (1) using a NASDAQ equally weighted index from the CRSP as a benchmark. The information ratio was annualized by multiplying the monthly IR calculated from equation (3) by the square root of 12, as shown in equation (4). The Z-scores for Estimated Beta, Jensen's alpha and the annualized Sharp information ratio are $0.140,1.836,{ }^{* *}$ and $1.63 * *$

* Significant at the 5\% level

** Significant at the $10 \%$ level 
Table 4: Performance of Portfolios of Debt Free Firms \& Matching Portfolios of Leveraged Firms, January 2002-June 2007
Debt free firms
Leveraged firms

Panel A: Energy Sector

\begin{tabular}{lll}
\hline Beta & 0.4837 & 0.9670 \\
Jensen's $\alpha$ & $0.0165^{*}$ & $0.0143^{*}$ \\
Sharp IR & 1.0905 & 1.1482
\end{tabular}

Panel B: Materials Sector

\begin{tabular}{lll}
\hline Beta & 0.7556 & 1.0265 \\
Jensen's $\alpha$ & $0.0144^{* *}$ & 0.0044 \\
Sharp IR & 0.7575 & 0.4245
\end{tabular}

Panel C: Industrial Sector

\begin{tabular}{lll}
\hline Beta & 1.1361 & 1.3459 \\
Jensen's $\alpha$ & $0.0083^{* *}$ & $0.0099^{* *}$ \\
Sharp IR & 0.7811 & 0.8614
\end{tabular}

Panel D: Consumer Discretionary Sector

\begin{tabular}{lll}
\hline Beta & 1.1143 & 1.1871 \\
Jensen's $\alpha$ & $0.00828^{* *}$ & 0.0012 \\
Sharp IR & 0.7597 & 0.1431
\end{tabular}

Panel E: Consumer Staples Sector

\begin{tabular}{lll}
\hline Beta & 0.2490 & 0.5759 \\
Jensen's $\alpha$ & -0.0020 & $0.0133^{*}$ \\
Sharp IR & -0.2032 & 0.9629 \\
\hline
\end{tabular}

Jensen's alpha is the measure of portfolio performance using a NASDAQ equally weighted index from the CRSP as a benchmark, and IR is the Sharp information ratio. The Jensen's alpha was computed from equation (1) and Sharp IR is calculated by dividing the estimated alpha from the regression in equation (1) by the regression standard error. This statistic is then annualized by multiplying the monthly IR by the square root of 12 . The Z-scores of the difference in the means of Beta, alpha, and Sharp IR are $0.280,1.2820$, and 1.1700 respectively.

* Significant at the 5\% level

** Significant at the $10 \%$ level 


\title{
Table 4: Performance of Portfolios of Debt Free Firms \& Matching Portfolios of Leveraged Firms, January 2002-June 2007 (cont.)
}

\author{
Debt free firms $\quad$ Leveraged firms
}

Panel F: Health Care Sector

\begin{tabular}{lll}
\hline Beta, $\alpha$ & 1.2314 & 0.9952 \\
Jensen's $\alpha .0084$ & 0.0063 \\
Sharp IR & 0.4805 & 0.1731
\end{tabular}

Panel G: Financial Sector

\begin{tabular}{lll}
\hline Beta & 0.7055 & 0.6096 \\
Jensen's $\alpha$ & $0.0081^{*}$ & $0.0638^{* *}$ \\
Sharp IR & 1.1076 & 0.8386
\end{tabular}

Panel H: IT Sector

\begin{tabular}{lll}
\hline Beta & 0.6964 & 1.2207 \\
Jensen's $\alpha$ & 0.0034 & 0.0069 \\
Sharp IR & 0.3537 & 0.3417
\end{tabular}

Panel I: All Sectors

\begin{tabular}{lll}
\hline Beta & 1.1856 & 0.9230 \\
Jensen's $\alpha$ & $0.0061^{*}$ & 0.0040 \\
Sharp IR & 1.130 & 1.1139
\end{tabular}

Jensen's alpha is the measure of portfolio performance using a NASDAQ equally weighted index from the CRSP as a benchmark, and IR is the Sharp information ratio. The Jensen's alpha was computed from equation (1) and Sharp IR is calculated by dividing the estimated alpha from the regression in equation (1) by the regression standard error. This statistic is then annualized by multiplying the monthly IR by the square root of 12 . The Z-scores of the difference in the means of Beta, alpha, and Sharp IR are 0.280, 1.2820, and 1.1700 respectively.

* Significant at the 5\% level

** Significant at the $10 \%$ level 